\title{
Genetic mechanism associated with congenital cytomegalovirus infection and analysis of effects of the infection on pregnancy outcome
}

\author{
J.M. Li' ${ }^{1}$, H.F. Zhang ${ }^{2}$, X.Q. Zhang ${ }^{3}$, G.L. Huang ${ }^{1}$, H.Z. Huang ${ }^{3}$ and W.W. Yu ${ }^{3}$ \\ 1Department of Clinical Laboratory, Xiamen Maternal and Children's Hospital, \\ Xiamen, Fujian, China \\ ${ }^{2}$ Department of Clinical Pediatric, Xiamen Maternal and Children's Hospital, \\ Xiamen, Fujian, China \\ 32Department of Obstetrics, Xiamen Maternal and Children's Hospital, Xiamen, \\ Fujian, China \\ Corresponding author: H.F. Zhang \\ E-mail: sunshinegirlkir@163.com \\ Genet. Mol. Res. 14 (4): 13247-13257 (2015) \\ Received May 5, 2015 \\ Accepted August 21, 2015 \\ Published October 26, 2015 \\ DOI http://dx.doi.org/10.4238/2015.October.26.21
}

\begin{abstract}
We aimed to compare the diagnostic value of various detection methods for cytomegalovirus (CMV) infection, to investigate the genetic mechanism associated with CMV infection in pregnant women, and to analyze the risk of sequelae development in fetuses with CMV infection. A total of 300 participants who had the same immunosuppressive regimen and received preemptive therapy for CMV infection were prospectively enrolled in this study; they included 289 vaccine trial participants. The gBabsorbed CMV IgG assay was performed for each vaccine trial participant. The healthy women were divided into 2 groups, and amniotic fluids were collected from them at $15-18$ weeks of gestation to test for CMV
\end{abstract}


seropositivity before conception by using IgM specific antibodies, CMVDNA, and IgG analysis. In 104 cases, cord blood sera and urine specimens were also collected from the infants and examined. The sensitivity and specificity of immediate-early messenger RNA and pp67 (late) messenger RNA detection by the nucleic acid sequence-based amplification technique was comparable to those of virus isolation and PCR. Furthermore, an association between single nucleotide polymorphisms in the TLR-2 gene and congenital CMV infection was observed and confirmed. Moreover, CMV infection during early pregnancy has been shown to have a much more severe effect on the pregnancy outcome compared to infection during later stages of pregnancy.

Key words: Cytomegalovirus; Pregnancy; Gene diagnosis

\section{INTRODUCTION}

Cytomegalovirus (CMV) is the most common cause of intrauterine infection, occurring in $0.3-2.1 \%$ of live-born infants (Stagno \& Whitley, 1985). Although only $10-16 \%$ of the infected fetuses are diagnosed with symptomatic congenital CMV infection (CCMVI) at birth, the disease causes severe symptoms including intrauterine growth restriction (IUGR), low birth weight, central nervous system disorder, multiple organ involvement with petechiae, hepatomegaly, splenomegaly, jaundice, pneumonia and encephalitis, leading to a high perinatal mortality rate and major neurological sequelae in approximately $91 \%$ of the surviving infants (Reynolds et al., 1974; Ross et al., 2005; Bate et al., 2010; Gorzer et al., 2010; Ikuta et al., 2012). In addition, 11-16\% of infants with asymptomatic CCMVI will develop long-term sequelae, namely progressive sensorineural hearing difficulty and mental retardation.

The potential risk factors influencing the clinical outcomes of CCMVI include both viral and host factors such as viral loads in the blood, CMV-IgG avidity index in pregnant women, as well as cytotoxic T lymphocyte responses and innate immunity in fetuses (Dahle et al., 1974; Gupta et al., 1996; Bate et al., 2010; Gorzer et al., 2010; Yamamoto et al., 2010; Ikuta et al., 2012). Ideally, the levels of systemic viral load in patients with symptomatic CCMVI should be monitored quantitatively to assess the clinical status, since qualitative measurements such as viral culture may only reflect viral infection rather than active disease (Ahlfors et al., 1983; Boppana et al., 2001). Monitoring of viral load by nucleic acid- or antigenemia-based assays has been shown to be particularly valuable in bone marrow and stem cell transplant patients. These assessments may not only predict the outcome of CMV infection, but also provide a solid basis for decisions on prophylactic or preemptive antiviral therapies.

This study was aimed at investigating the latest prevalence and risk of multiple CMV infection in pregnant women, as well as the types of maternal CMV infection associated with congenital CMV infection, to explore the underlying molecular mechanism of action and to build an analytic model to predict the pregnancy outcome in CMV infection. Specifically, the factors affecting the pregnancy outcome were analyzed by a variety of molecular techniques including fluorescence real-time quantitative PCR, sequencing, microarray, and mass spectrometry. The candidate factors include CMV load, CMV gB genotype, the immune-related genetic susceptibility in pregnant women, and infection by other pathogens such as Toxoplasma gondii (TOX), rubella 
virus (RV), herpes simplex virus (HSV), parvovirus, Epstein-Barr virus (EBV), and hepatitis B virus. Future studies will need to be performed on a much larger number of cases to build a mathematical model for the prediction of the pregnancy outcome in CCMVI. Our results provide a scientific basis for the prevention of serious clinical outcomes in CCMVI.

\section{MATERIAL AND METHODS}

\section{Participants and specimens}

A total of 300 healthy pregnant women were selected, that included 289 vaccine trial participants. The participants were divided into 2 groups-the first trimester group and later infection group in this study. The gB-absorbed CMV IgG assay was performed for each vaccine trial participant as described previously (Gouarin et al., 2002; Watzinger et al., 2004; Cheeran et al., 2009). Amniotic fluid (AF) was collected from these women at 15-18 weeks of gestation to test for CMV-seropositive before conception by using IgM specific antibodies, CMV-DNA, and IgG analysis. In 104 cases, cord blood sera and urine specimens were collected from the infants and examined by different HCMV assays.

\section{Detection of CMV DNA}

\section{Sample preparation}

Amniotic fluid samples $(200-550 \mu \mathrm{L})$ were centrifuged at $12,000 \mathrm{~g}$ for $15 \mathrm{~min}$ at room temperature. A total of $10 \mathrm{~mL}$ urine sample was centrifuged at $850 \mathrm{~g}$ for $20 \mathrm{~min}$, and the virus was pelleted by centrifugation at 36,000 rpm for $1 \mathrm{~h}$. The pellet was suspended in $200 \mu \mathrm{L}$ lysis buffer containing $55 \mathrm{mM} \mathrm{KCl}, 10 \mathrm{mM}$ Tris-HC1 (pH 8.0), $2.5 \mathrm{mM} \mathrm{MgC1}_{2}, 0.6 \%$ Nonidet P40, 0.6\% Tween 20 , and $100 \mu \mathrm{g} / \mathrm{mL}$ proteinase $\mathrm{K}$. The mixture was incubated at $55^{\circ} \mathrm{C}$ for $2 \mathrm{~h}$ to lyse the cells and then at $94^{\circ} \mathrm{C}$ for $5 \mathrm{~min}$ to inactivate the proteinase $\mathrm{K}$. The lysed samples were stored at $-25^{\circ} \mathrm{C}$ until use. Serum and cord blood serum samples $(150 \mu \mathrm{L})$ were mixed with $500 \mu \mathrm{L}$ lysis buffer and processed as described above.

\section{Polymerase chain reaction (PCR)}

A 406-bp DNA segment was amplified from the genome of CMV by PCR. The amplification reaction mixture consisted of $20 \mathrm{mM}(\mathrm{NH} 4)$ 2804, $76 \mathrm{mM}$ Tris-HC1 (pH 8.9), 0.2\% (w/v) Tween, 1.0 $\mathrm{mM} \mathrm{MgCl}, 200 \mu \mathrm{M}$ deoxynucleoside triphosphates, 50 pmol each primer, $10 \mu \mathrm{L}$ DNA sample, and 2.0 units Taq polymerase (Advanced Biotechnologies Itd; Surrey, UK) in a final reaction volume of $100 \mu \mathrm{L}$. The samples were overlaid with $100 \mu \mathrm{L}$ mineral oil (Amresco Itd; Ohio, USA) and heated at $92^{\circ} \mathrm{C}$ for $10 \mathrm{~min}$ for template denaturation, followed by 40 cycles, each consisting of $93^{\circ} \mathrm{C}$ for $1 \mathrm{~min}, 56^{\circ} \mathrm{C}$ for $2 \mathrm{~min}$, and $73^{\circ} \mathrm{C}$ for $3 \mathrm{~min}$, and a final extension step at $73^{\circ} \mathrm{C}$ for $7 \mathrm{~min}$. The DNA sequence of the forward and reverse primer was $5^{\prime}$ Biotin-CCAAGC GGC CTC TGA TAA CCAAGC C-3' (nucleotide position 722-725) and 5'-CAG CAC CAT CCT CCT CTT CCT CTG G-3' (nucleotide position 1161-1151), respectively. Biotinylated PCR products were analyzed by gel electrophoresis on a $1.3 \%$ agarose gel. The resultant RNA:DNA hybrids were captured through biotin onto the surface of streptavidin-coated microwells. Immobilized hybrids were reacted with an antiRNA-DNA 
specific antibody conjugated to alkaline phosphatase and detected using a colorimetric substrate. Absorbance values of each sample was determined under $403 \mathrm{~nm}$ and compared with that of positive and negative controls supplied by DIGENE diagnostics Inc. (Silver Spring, MD, USA). Positive cutoff values were obtained from the mean Abs value of the amplified negative PCR control.

\section{gB-absorbed CMV IgG and IgM assay}

IgG capture ELISA was used to detect gB-absorbed CMV IgG and IgM. Recombinant Staphylococcal protein A (R\&D systems Inc, Minneapolis, USA) was added to the solid phase for capture saliva IgG (R\&D systems Inc, Minneapolis, USA), followed by binding of biotinylated tachyzoite saline antigen (R\&D systems Inc, Minneapolis, USA), which was quantitated by using avidin peroxidase (R\&D systems Inc, Minneapolis, USA). The reaction was revealed using two chromogenic peroxidase substrates (R\&D systems Inc, Minneapolis, USA), such as OPD and $\mathrm{TMB}$, with appropriate controls in each plate.

\section{SNP detection}

Blood samples $(5 \mu \mathrm{L})$ were obtained from each participant for genomic DNA extraction using the E.Z.N.A. Blood Midi Kit (Omega Bio-Tek, Norcorss, GA, USA). TLR2, TLR4, TLR9 SNPs were selected and genotyped using the Sequenom iPLEX platform (Sequenom Inc., San Diego, CA, USA), and laboratory persons who conducted the genotyping assays were blinded to patients' information. Quality controls were implemented in each assay for genotyping, and SNPs with call rate $>98 \%$ were included for further analysis. Differences in the prevalence of genotyped polymorphisms between the CMV infection group and the healthy control group were estimated by odds ratios (ORs), 95\% confidence intervals (95\% Cls), and $\mathrm{P}$ values. ORs and 95\% Cls were calculated for each genotype in comparison to the reference genotype (homozygous genotype for the prevalent allele). $\mathrm{P}$ values were derived from the Chi-square test. $\mathrm{P}$ values $<0.05$ were considered to indicate statistical significance. To adjust the $P$ values for multiple comparisons, Bonferroni multiple correction of $\mathrm{P}$ values was applied.

\section{NASBA assay for HCMV immediate-early messenger RNA (IEmRNA) and pp67 (late) messenger RNA}

HCMV IEmRNA and pp67 mRNA were determined by the nucleic acid sequence-based amplification (NASBA) technique, following the manufacturer (Organon, Teknika, USA) instructions. In brief, nucleic acids from $100 \mu \mathrm{L}$ whole blood were isolated by the method described by Lazzarotto T et al. (2000). System control (SC) RNA was added to samples before nucleic acid isolation as a positive control for RNA isolation, amplification, and detection. The SC RNA could be distinguished from wild-type (wt) RNA by the insertion of a 134-nt fragment (Enders et al., 2001; Gouarin et al., 2001). SC and wt IEmRNAs were amplified with a primer that contained a T7 promoter and a reverse primer. Amplification products were detected by electrochemiluminescence with a common capture probe coupled to magnetic beads and by 2 specific (wt- and SC-specific) ruthenium-labeled oligonucleotide detection probes (Enders et al., 2001; Gouarin et al., 2001). NASBA sensitivity for IEmRNA was 70 copies $/ 10 \mu \mathrm{L}$ whole blood. 


\section{Virologic analysis of antigenemia and DNAemia}

Virologic analysis was performed by prospective quantitation of antigenemia and DNAemia. Antigenemia was quantitated by counting the number of peripheral blood leukocytes positive for pp65 (Lazzarotto et al., 2000). Viral DNA was quantitated in $10 \mu \mathrm{L}$ whole blood by PCR in the presence of 100 copies of an internal control and in parallel with a series of external standards (Enders et al., 2001). Single-step PCR consistently amplified samples containing $>10$ genome equivalents (GEs), whereas samples containing 1-10 GEs were detected by nested PCR and were assigned an arbitrary value of 5 GEs.

\section{Antigenemia Assay of CMV}

The CMV antigenemia assays were performed using ethylenediaminetetraacetic acidtreated whole blood samples, according to previously reported methods (Ho et al., 1998). The blood samples were fractionated by dextran sedimentation and erythrocyte lysis. A cytospin slide was prepared after centrifugation of the blood samples, fixed with formaldehyde, sequentially immunostained with a monoclonal antibody (C10/C11) against the pp65 antigen (Biotest, Dreieich, Germany), and reacted with fluorescein isothiocyanate-conjugated goat anti-mouse IgG antibody (Biotest, Dreieich, Germany). The results were expressed as the number of CMV pp65-positive cells per slide. Positive CMV antigenemia was defined as at least 1 pp65-positive cell per $2 \mathrm{x}$ $10^{5}$ PMNs.

\section{Statistical Analyses}

The prevalence of congenital CMV among children with permanent childhood hearing impairment (PCHI) was calculated. Statistical analyses were performed using SPSS version 16.0 (SPSS Inc., Chicago, IL, USA). The $X^{2}$-test was used to determine the differences in baseline characteristics (Stagno et al., 1985; Mitchell et al., 2002). Linear regression modeling was used to analyze the developmental outcome based on the CDI-NL. Adjustment was made for age at examination and severity of hearing loss. $P$ values $<0.05$ were considered to indicate statistical significance.

\section{RESULTS}

\section{Clinical characteristics of infant subjects}

A total of 39 infants were enrolled in this study including 20 infants in the CMV infection group and 19 infants in the control group. The dried umbilical cord specimen from each infant was analyzed for CMV-DNA detection. In the CMV infection group, 11 infants were asymptomatic and 9 had one or more of the following manifestations during initial examination: abnormal ABR in 8 cases, hepatosplenomegaly in 4 , hepatitis in 3 , jaundice in 1 , thrombocytopenia with petechiae in 2 , chorioretinitis in 2, and intracranial calcifications in 5 . The clinical characteristics of these infant subjects were summarized in Table 1.

Prenatal diagnosis of CMV infection is a very delicate task and should never be based on the result of a single test. We have recently evaluated commercially available molecular assays 
other than PCR analysis for the detection of CMV in AF samples (Revello et al., 1995). In this study, $69 \mathrm{AF}$ samples were analyzed by virus isolation and PCR, and subsequently tested for CMV IE mRNA and pp67 mRNA by the NASBA technique. As shown in Table 2, similar sensitivity was observed with all four methods (Revello et al., 1995; Lazzarotto et al., 2000; Enders et al., 2001; Gouarin et al., 2001), whereas the specificity of all assays was $100 \%$ with the exception of one false-positive result detected by the NASBA assay of IE mRNA, yielding a specificity of $96.8 \%$. These results suggested that NASBA assays for both IE mRNA and pp67 mRNA can be used as first choice detection methods or methods to confirm results obtained by PCR in those laboratories where virus isolation is not feasible.

\begin{tabular}{|c|c|c|c|c|}
\hline & \multirow[t]{2}{*}{ Control $(\mathrm{N}=19)$} & \multicolumn{3}{|c|}{ CMVI } \\
\hline & & Total $(\mathrm{N}=20)$ & Normal ABR (N = 11) & Abnormal ABR $(\mathrm{N}=9)$ \\
\hline Gestational age (weeks) & $37(36-41)$ & $37(31-41)$ & $37(35-41)$ & $38(31-39)$ \\
\hline Birth weight $(\mathrm{g})$ & $2791(2218-3688)$ & $2916(1378-3840)$ & $3170(2362-3840)$ & $2319(1378-3160)$ \\
\hline Male/female & $8 / 11$ & $8 / 12$ & $4 / 7$ & $4 / 5$ \\
\hline $\begin{array}{l}\text { Postconceptional age at the } \\
\text { time of brain CT (weeks) }\end{array}$ & $37(36-42)$ & $39(34-52)$ & $41(38-45)$ & $39(34-52)$ \\
\hline $\begin{array}{l}\text { Postconceptional age at the } \\
\text { time of ABR evaluation (weeks) }\end{array}$ & $38(36-42)$ & $41(34-48)$ & $41(39-45)$ & $39(34-48)$ \\
\hline
\end{tabular}

$\mathrm{ABR}=$ auditory brainstem response.

Table 2. Diagnostic value (with respect to virus detection at birth) of different assays for prenatal diagnosis of congenital infection in 104 fetuses of 102 mothers with primary HCMV infection during pregnancy.

\begin{tabular}{|c|c|c|c|c|c|c|c|c|}
\hline Sample & HCMV assay & Test result & Infected & Uninfected & Sensitivity & Specificity & PPV & NPV \\
\hline \multirow[t]{12}{*}{ Fetal blood } & \multirow[t]{2}{*}{ Antigenemia } & Negative & 18 & 45 & \multirow[t]{2}{*}{$61.2 \%$} & \multirow[t]{2}{*}{$100 \%$} & \multirow[t]{2}{*}{$100 \%$} & \multirow[t]{2}{*}{$72.9 \%$} \\
\hline & & Positive & 23 & 0 & & & & \\
\hline & \multirow[t]{2}{*}{ Viremia } & Negative & 25 & 39 & \multirow[t]{2}{*}{$35.9 \%$} & \multirow[t]{2}{*}{$100 \%$} & \multirow[t]{2}{*}{$100 \%$} & \multirow[t]{2}{*}{$65.1 \%$} \\
\hline & & Positive & 15 & 0 & & & & \\
\hline & \multirow[t]{2}{*}{ DNAemia } & Negative & 7 & 36 & \multirow[t]{2}{*}{$82.7 \%$} & \multirow[t]{2}{*}{$100 \%$} & \multirow[t]{2}{*}{$100 \%$} & \multirow[t]{2}{*}{$84.3 \%$} \\
\hline & & Positive & 33 & 0 & & & & \\
\hline & \multirow[t]{2}{*}{ IEmRNA } & Negative & 4 & 20 & \multirow[t]{2}{*}{$81.9 \%$} & \multirow[t]{2}{*}{$100 \%$} & \multirow[t]{2}{*}{$100 \%$} & \multirow[t]{2}{*}{$86.1 \%$} \\
\hline & & Positive & 15 & 0 & & & & \\
\hline & \multirow[t]{2}{*}{ pp67 mRNA } & Negative & 3 & 13 & \multirow[t]{2}{*}{$64.9 \%$} & \multirow[t]{2}{*}{$100 \%$} & \multirow[t]{2}{*}{$100 \%$} & \multirow[t]{2}{*}{$72.6 \%$} \\
\hline & & Positive & 9 & 0 & & & & \\
\hline & \multirow{2}{*}{ IgM antibody } & Negative & 17 & 41 & \multirow[t]{2}{*}{$51.7 \%$} & \multirow[t]{2}{*}{$100 \%$} & \multirow[t]{2}{*}{$100 \%$} & \multirow[t]{2}{*}{$68.7 \%$} \\
\hline & & Positive & 24 & 0 & & & & \\
\hline \multirow[t]{8}{*}{ Amniotic fluid } & \multirow[t]{2}{*}{ Virus isolation } & Negative & 11 & 51 & \multirow[t]{2}{*}{$81.8 \%$} & $100 \%$ & $100 \%$ & $82.8 \%$ \\
\hline & & Positive & 43 & 0 & & & & \\
\hline & DNA & Negative & 4 & 45 & $91.5 \%$ & $100 \%$ & $100 \%$ & $91.2 \%$ \\
\hline & & Positive & 47 & 0 & & & & \\
\hline & IEmRNA & Negative & 5 & 44 & $91.2 \%$ & $96.8 \%$ & $95.3 \%$ & $92.7 \%$ \\
\hline & & Positive & 28 & 2 & & & & \\
\hline & pp67 mRNA & Negative & 2 & 43 & $92.1 \%$ & $100 \%$ & $100 \%$ & $91.8 \%$ \\
\hline & & Positive & 29 & 0 & & & & \\
\hline
\end{tabular}

PPV = positive predictive value; NPV = negative predictive value; IEmRNA = immediate-early messenger RNA; pp67 mRNA = pp67 (late) messenger RNA. (Revello and Gerna, unpublished data). N = Negative, P = Positive.

\section{Statistical analyses of genotype}

As shown in Table 3, genotype and allelic frequencies of all SNPs of TLR2, TLR4, TLR9 genes were in Hardy-Weinberg equilibrium among each group (data not shown) [18-20]. In this study, differences in the prevalence of genotyped polymorphisms between the CMV infection group 
and the healthy control group were estimated by odds ratios (ORs), 95\% confidence intervals (95\% $\mathrm{Cls}$ ), and $\mathrm{P}$ values. ORs and $95 \% \mathrm{Cls}$ were calculated for each genotype in comparison to the reference genotype (homozygous genotype for the prevalent allele). $P$ values were derived using the Chi-square test. $P$ values $<0.05$ were considered to indicate statistical significance. To adjust the $\mathrm{P}$ values for multiple comparisons, Bonferroni multiple correction of $\mathrm{P}$ values was applied.

Table 3. Association between single nucleotide polymorphisms in the TLR-2, 4 , and 9 genes with CCMVI.

\begin{tabular}{|c|c|c|c|c|c|c|}
\hline \multirow[t]{2}{*}{ Gene } & \multirow[t]{2}{*}{ Genetic model } & \multirow[t]{2}{*}{ Genotype } & \multicolumn{4}{|c|}{ Healthy control group (A) or CCMVI group (B) } \\
\hline & & & A (\%) & B (\%) & OR $(95 \% \mathrm{Cl})$ & $P$ value \\
\hline \multirow[t]{7}{*}{ TLR-2 } & Codominant & AA & 19.7 & 34.5 & 1 & NS \\
\hline & & $A G$ & 62.8 & 47.1 & 0.43 & \\
\hline & & GG & 17.4 & 18.4 & 0.60 & \\
\hline & Dominant & AA & 19.7 & 34.5 & 1 & 0.030 \\
\hline & & $A G+G G$ & 80.2 & 65.5 & 0.47 & \\
\hline & Recessive & $A A+A G$ & 82.6 & 81.6 & 1 & NS \\
\hline & & GG & 17.4 & 18.4 & 1.07 & \\
\hline \multirow[t]{7}{*}{ TLR-4 } & Codominant & GG & 57.1 & 51.7 & 1 & NS \\
\hline & & $\mathrm{GC}$ & 35.7 & 40.2 & 1.24 & \\
\hline & & $\mathrm{CC}$ & 7.1 & 8 & 1.24 & \\
\hline & Dominant & GG & 57.1 & 51.7 & 1 & NS \\
\hline & & $\mathrm{GC}+\mathrm{CC}$ & 42.9 & 48.3 & 1.24 & \\
\hline & Recessive & $G G+G C$ & 92.9 & 92 & 1 & NS \\
\hline & & CC & 7.1 & 8 & 1.14 & \\
\hline \multirow[t]{4}{*}{ TLR-9 } & Codominant & AA & 29.1 & 25.3 & 1 & NS \\
\hline & & AG & 43 & 54 & 1.44 & \\
\hline & Dominant & AA & 29.1 & 25.3 & 1 & NS \\
\hline & & $A A+A G$ & 70.9 & 74.7 & 1.21 & \\
\hline
\end{tabular}

$\mathrm{CCMVI}=$ congenital cytomegalovirus infection; $\mathrm{OR}=$ odds ratio; $\mathrm{Cl}=$ confidence interval; $\mathrm{NS}=$ not significant. $\mathrm{P}$ values were derived using the Chi-square test. $P$ values $<0.05$ were considered to indicate statistical significance.

\section{Detection of CMV infection by CMV culture}

The gB-absorbed CMV IgG assay was performed on each of the 289 vaccine trial participants. Subjects with positive results in the gB-absorbed CMV IgG assay were compared with those with negative results (Table 4). Serologic evidence of CMV infection was found in 26/289 $(8.99 \%)$ study participants who had gB-absorbed CMV IgG levels $>5.0 \mathrm{AU} / \mathrm{mL}$. The gB-absorbed CMV IgG levels of their first positive serum ranged from 15.7 to $251.0 \mathrm{AU} / \mathrm{mL}$ with a mean of 77.0 $\mathrm{AU} / \mathrm{mL}$ and a median of $43.6 \mathrm{AU} / \mathrm{mL}$. Out of the 1142 tested serum samples, 1091 were negative (gB-absorbed CMV IgG level $<5.0 \mathrm{AU} / \mathrm{mL}$, range 0.0-3.7 AU/mL). All subjects with positive gBabsorbed CMV IgG results were also found to be positive upon repeat testing at their next study visit. The gB-absorbed CMV IgG levels of the first follow-up serum collected post-infection from the 23 positive subjects ranged from 14.0 to $255.0 \mathrm{AU} / \mathrm{mL}$ with a mean of $95.5 \mathrm{AU} / \mathrm{mL}$ and a median of 75.6 AU/mL. The median interval from the last negative to first positive gB-absorbed CMV IgG for these subjects was 14 weeks.

Examples of serial gB-absorbed CMV IgG results of 2 vaccine trial participants before and after CMV infection during the trial are shown in Figure 1 (Gaytant et al., 2002; Gouarin et al., 2002; Compton et al., 2003; Tanaka et al., 2006; Revello et al., 2008). Subjects A and B were both found to be infected with CMV at 9 months after the initial immunization. Their gB-absorbed CMV IgG levels prior to infection remained as low as that during the prevaccine visit, ranging from 0.0 to 1.7 $\mathrm{AU} / \mathrm{mL}$. In contrast, their serial gB-absorbed CMV IgG results post-infection increased dramatically and ranged from 43.4 to $181.0 \mathrm{AU} / \mathrm{mL}$. 
Table 4. gB-absorbed CMV IgG assay of vaccine trial participants.

\begin{tabular}{lccccc}
\hline & \multicolumn{2}{c}{ CMV infection } & $\begin{array}{c}\text { Range of gB-absorbed } \\
\text { CMV IgG levels (AU/mL) }\end{array}$ & $\begin{array}{c}\text { Mean of gB-absorbed } \\
\text { CMV IgG levels (AU/mL) }\end{array}$ & $\begin{array}{c}\text { Median of gB-absorbed } \\
\text { CMV IgG levels (AU/mL) }\end{array}$ \\
\cline { 2 - 3 } & Positive (n\%) & Negative (n\%) & & $77.0^{*}$ & $43.6^{*}$ \\
\hline Participants ( $\mathrm{N}=289)$ & $26(8.99 \%)$ & $263(91.01 \%)$ & $15.7-251.0^{*}$ & $<5.0^{*}$ & - \\
$\begin{array}{l}\text { Serum samples } \\
(\mathrm{N}=1142)\end{array}$ & $51(4.46 \%)$ & $1091(95.54 \%)$ & $0.0-3.7^{*}$ & 95.5 & 75.6 \\
$\begin{array}{c}\text { First follow-up for } \\
\text { positive subjects }\end{array}$ & $23(100 \%)$ & 0 & $14.0-255.0$ & & \\
\hline
\end{tabular}

*The gB-absorbed CMV IgG levels were detected in positive serum samples; "the gB-absorbed CMV IgG levels were detected in negative serum samples.
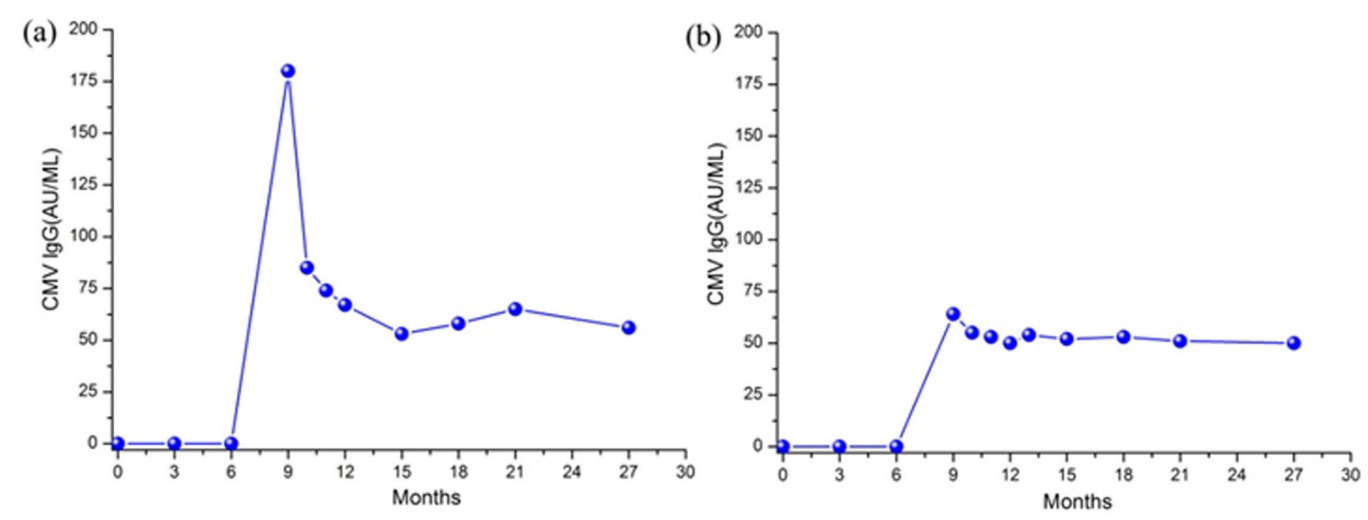

Figure 1. Serial gB-absorbed CMV IgG results for two vaccine trial participants before and after CMV infection

\section{Pregnancy outcome after CMV infection}

The overall rate of CNS sequelae in the first trimester group (12/36, 33\%) was only slightly different from that in later infection group $(6 / 40,15 \% ; P=0.068, R R=2.2)$. Four $(12 \%)$ of the first trimester cases had more than two CNS sequelae, compared with none of the later infection group $(P=0.038)$ (Lukacsi et al., 2001; Kishore et al., 2011). Frequencies of the major CNS sequelae are shown in Figure 2.

All but five patients (one from the first trimester group and four from the later infection group) had follow-up evaluations for the determination of pregnancy outcome. The major abnormality was sensorineural hearing loss. The incidence of infants with sensorineural hearing loss in the first trimester group $(9 / 36,27 \%)$ was significantly higher than that in the later infection group $(1 / 40,2.5 \% ; P=0.01, R R=9.6)$. Further, neuropsychologic examinations were completed on 24 infants in the first trimester group and 26 in the later infection group. The incidence of mentally retarded infants $(I Q<70)$ in the first trimester and later infection group was $17 \%$ and $7.7 \%$, respectively, revealing no significant difference between the two groups. Moreover, seizure disorder, cerebral palsy, and chorioretinitis were confirmed in 3,2, and 1 infants, respectively, from the first trimester group, whereas 1 case of seizures and 1 of chorioretinitis was observed in the later group. 


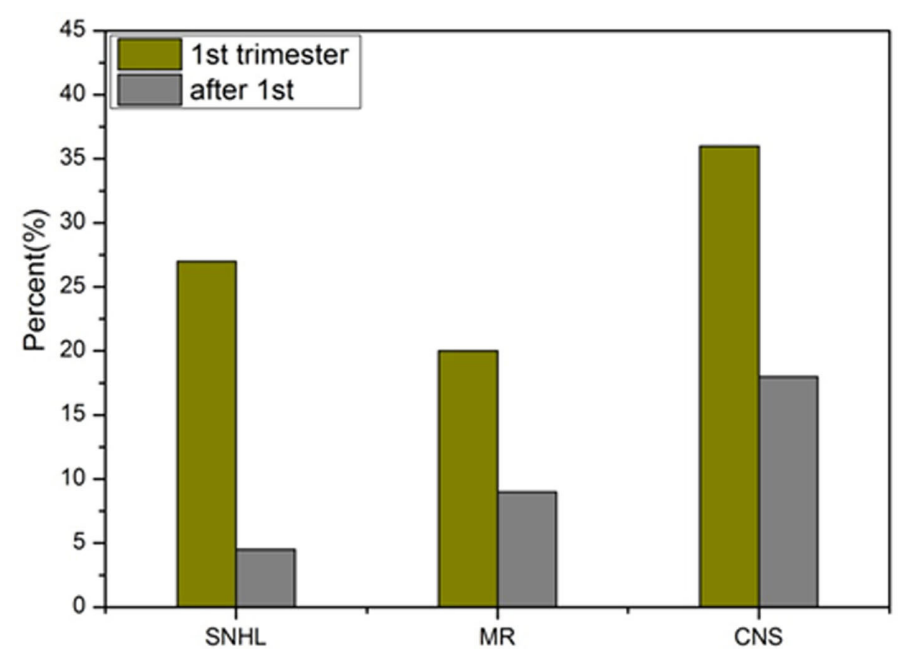

Figure 2. Percentage of patients with central nervous system sequelae in CCMVI according to gestational age at the time of maternal infection. $\mathrm{SNHL}=$ sensorineural hearing loss; $\mathrm{MR}=$ mental retardation $(\mathrm{IQ}<70) ; \mathrm{CNS}=$ central nervous system, indicating patients with any $C N S$ sequelae. ${ }^{*} P=0.01 ; R R=9.6$. ${ }^{* *} P=0.07 ; R R=2.2$.

\section{DISCUSSION}

While CMV can be transmitted from the mother to the fetus, congenital CMV infection can even occur following recurrent maternal infection. Therefore, the birth of one congenitally infected infant does not preclude the possibility of in-utero infection of a subsequent baby.

Moreover, a recent study has shown that 8 out of 47 infants with symptomatic CCMVI were born to mothers with a confirmed non-primary or recurrent infection (Lukacsi et al., 2001), suggesting that symptomatic CCMVI after recurrent maternal infection occurs more frequently than previously thought. However, the risk of major fetal injury associated with recurrent CMV infection is believed to be considerably lower than that of primary infection, probably due to the protective effect of pre-existing CMV antibodies (Gouarin et al., 2002; Tanaka et al., 2006; Revello et al., 2008). Live babies delivered in all the reported cases exhibited typical clinical features of congenital CMV infection, such as jaundice, hepatosplenomegaly, and thrombocytopenia. To the best of our knowledge, this is the first reported case of severe congenital CMV infection causing intrauterine fetal death after recurrent maternal infection, in which abnormal findings such as fetal hydrops were clearly identified by antenatal ultrasonography (Kishore et al., 2011).

Many infants born to mothers with primary or recurrent infection are asymptomatic and can develop normally despite viremia in utero and postnatally, and shedding of virus in urine and saliva for years after birth. Infants acquiring CMV postnatally exhibit similar patterns of viremia and viral excretion without symptoms. Even when $\mathrm{CMV}$ is acquired through transfusion in very low birth weight infants (weight lower than $1250 \mathrm{~g}$ ) of seronegative mothers, the infants may become ill but do not develop the symptoms acquired in utero after primary maternal infection (Reynolds et al., 1974; Stagno \& Whitley, 1985; Ross et al., 2005).

It is important to note the blind spot of the current clinical trial. It may be speculated that if $\mathrm{CMV}$ infections occur in recipients of $\mathrm{CMV} \mathrm{gB}$ vaccine, they might be modified by the presence of vaccine-induced immunity, and therefore might not be detectable by the same approaches that 
are effective in nonimmunized subjects with infection (Revello et al., 1995). To address this, in the future, we will confirm CMV infection in all participants in this trial by standard CMV IgG and immunoblot assays of serum, and PCR analyses of whole blood, urine, and saliva samples.

CMV infection has been known to significantly contribute to sensorineural hearing loss (SNHL) in many infants. Although most infants with CCMVI do not develop hearing loss, it is difficult to predict which infants with CCMVI will develop hearing loss and, among those who do develop loss, whether or not the loss will continue to deteriorate. Therefore, it is crucial to clarify the genetic mechanism associated with CMV infection and to build an analytical model for the prediction of pregnancy outcome in women with CMV infection (Compton et al., 2003). In this study, an association between SNPs in the TLR-2 gene and CMV infection was identified. Furthermore, it was shown that the incidence of sensorineural hearing loss in infants in the first trimester group was significantly higher than that in the later infection group, suggesting that CMV infection during early pregnancy has a much more severe effect on the pregnancy outcome.

\section{Conflicts of interest}

The authors declare no conflict of interest.

\section{REFERENCES}

Ahlfors K, Forsgren M, Ivarsson SA, Harris S, et al. (1983). Congenital cytomegalovirus infection: on the relation between type and time of maternal infection and infant's symptoms. Scand. J. Infect. Dis. 15: 129-138.

Bate SL, Dollard SC and Cannon MJ (2010). Cytomegalovirus seroprevalence in the United States: the national health and nutrition examination surveys, 1988-2004. Clin. Infect. Dis. 50: 1439-1447.

Boppana SB, Rivera LB, Fowler KB, Mach M, et al. (2001). Intrauterine transmission of cytomegalovirus to infants of women with preconceptional immunity. N. Engl. J. Med. 344: 1366-1371.

Cheeran MC, Lokensgard JR and Schleiss MR (2009). Neuropathogenesis of congenital cytomegalovirus infection: disease mechanisms and prospects for intervention. Clin. Microbiol. Rev. 22: 99-126.

Compton T, Kurt-Jones EA, Boehme KW, Belko J, et al. (2003). Human cytomegalovirus activates inflammatory cytokine responses via CD14 and Toll-like receptor 2. J. Virol. 77: 4588-4596.

Dahle AJ, McCollister FP, Hamner BA, Reynolds DW, et al. (1974). Subclinical congenital cytomegalovirus infection and hearing impairment. J. Speech Hear. Disord. 39: 320-329.

Enders G, Bader U, Lindemann L, Schalasta G, et al. (2001). Prenatal diagnosis of congenital cytomegalovirus infection in 189 pregnancies with known outcome. Prenat. Diagn. 21: 362-377.

Gaytant MA, Steegers EA, Semmekrot BA, Merkus HM, et al. (2002). Congenital cytomegalovirus infection: review of the epidemiology and outcome. Obstet. Gynecol. Surv. 57: 245-256.

Gorzer I, Kerschner H, Redlberger-Fritz M, and Puchhammer-Stöckl E (2010). Human cytomegalovirus (HCMV) genotype populations in immunocompetent individuals during primary HCMV infection. J. Clin. Virol. 48: 100-103.

Gouarin S, Palmer P, Cointe D, Rogez S, et al. (2001). Congenital HCMV infection: a collaborative and comparative study of virus detection in amniotic fluid by culture and by PCR. J. Clin. Virol. 21: 47-55.

Gouarin S, Gault E, Vabret A, Cointe D, et al. (2002). Real-time PCR quantification of human cytomegalovirus DNA in amniotic fluid samples from mothers with primary infection. J. Clin. Microbiol. 40: 1767-1772.

Gupta CK, Leszczynski J, Gupta RK, and Siber GR (1996). IgG subclass antibodies to human cytomegalovirus (CMV) in normal human plasma samples and immune globulins and their neutralizing activities. Biologicals 24: 117-124.

Ho SK, Lo CY, Cheng IK, and Chan TM (1998). Rapid cytomegalovirus pp65 antigenemia assay by direct erythrocyte lysis and immunofluorescence staining. J. Clin. Microbiol. 36: 638-640.

Ikuta K, Ishioka K, Sato Y, Imamura T, et al. (2012). A novel real-time PCR method for determination and quantification of each cytomegalovirus glycoprotein $\mathrm{H}$ subtype in clinical samples. J. Clin. Microbiol. 50: 499-501.

Kishore J, Misra R, Paisal A, and Pradeep Y (2011). Adverse reproductive outcome induced by Parvovirus B19 and TORCH infections in women with high-risk pregnancy. J. Infect. Dev. Ctries. 5: 868-73.

Lazzarotto T, Varani S, Guerra B, Nicolosi A, et al. (2000). Prenatal indicators of congenital cytomegalovirus infection. J. Pediatr. 137: 90-95. 
Lukacsi A, Tarodi B, Endreffy E, Babinski A, et al. (2001). Human cytomegalovirus gB genotype 1 is dominant in congenital infections in South Hungary. J. Med. Virol. 65: 537-542.

Mitchell DK, Holmes SJ, Burke RL, Duliege AM, et al. (2002). Immunogenicity of a recombinant human cytomegalovirus gB vaccine in seronegative toddlers. Pediatr. Infect. Dis. J. 21: 133-138.

Revello MG, Baldanti F, Furione M, Sarasini A, et al. (1995). Polymerase chain reaction for prenatal diagnosis of congenital human cytomegalovirus infection. J. Med. Virol. 47: 462-466.

Revello MG, Campanini G, Piralla A, Furione M, et al. (2008). Molecular epidemiology of primary human cytomegalovirus infection in pregnant women and their families. J. Med. Virol. 80: 1415-1425.

Reynolds DW, Stagno S, Stubbs KG, Dahle AJ, et al. (1974). Inapparent congenital cytomegalovirus infection with elevated cord IgM levels. Casual relation with auditory and mental deficiency. N. Engl. J. Med. 290: 291-296.

Ross SA, Novak Z, Ashrith G, Rivera LB, et al. (2005). Association between genital tract cytomegalovirus infection and bacterial vaginosis. J. Infect. Dis. 192: 1727-1730.

Stagno S, Tinker MK, Elrod C, Fuccillo DA, et al. (1985). Immunoglobulin M antibodies detected by enzyme-linked immunosorbent assay and radioimmunoassay in the diagnosis of cytomegalovirus infections in pregnant women and newborn infants. J. Clin. Microbiol. 21: 930-935.

Stagno S and Whitley RJ (1985). Herpesvirus infections of pregnancy. Part I: Cytomegalovirus and Epstein-Barr virus infections. N. Engl. J. Med. 313: 1270-1274.

Tanaka K, Yamada H, Minami M, Kataoka S, et al. (2006). Screening for vaginal shedding of cytomegalovirus in healthy pregnant women using real-time PCR: correlation of CMV in the vagina and adverse outcome of pregnancy. J. Med. Virol. 78: 757-759.

Watzinger F, Suda M, Preuner S, Baumgartinger R, et al. (2004). Real-time quantitative PCR assays for detection and monitoring of pathogenic human viruses in immunosuppressed pediatric patients. J. Clin. Microbiol. 42: 5189-5198.

Yamamoto AY, Mussi-Pinhata MM, Boppana SB, Novak Z, et al. (2010). Human cytomegalovirus reinfection is associated with intrauterine transmission in a highly cytomegalovirus-immune maternal population. Am. J. Obstet. Gynecol. 202: 297. e1-8. 